\title{
Arab Spring...Islamists-Seculars Struggle to Control Egypt A CDA Study from AJE's Ideological Perspective
}

\author{
Hanan Al- Radhi (Corresponding author) \\ School of Languages, Literacies and Translation, USM, Malaysia \\ E-mail: halradhi2012@gmail.com \\ Ambigapathy Pandian \\ School of Languages, Literacies and Translation, USM, Malaysia \\ E-mail: ambiga@usm.my \\ Tengku Sepora Tengku Mehdi \\ School of Languages, Literacies and Translation, USM, Malaysia \\ E-mail: Sepora@usm.my
}

Received: 14-02-2016

Published: 01-07-2016
Accepted: 05-05-2016

doi:10.7575/aiac.ijalel.v.5n.4p.142
Advance Access Published: May 2016

URL: http://dx.doi.org/10.7575/aiac.ijalel.v.5n.4p.142

\begin{abstract}
The current study investigates the Arab spring upheaval consequences Egypt witnessed after 2011 popular revolution as reflected by AJE (Al-Jazeera English) in its online news article. The primary concern is to unveil AJE's hidden ideological view towards the internal conflict in Egypt investigating its discoursal positive "Self" and negative "Other" representations. Within the linguistic analysis, macro and micro structures of AJE's online news article were analyzed. At the macro level, the semantic macrostructure of AJE's article was outlined to determine its global meaning. At the micro level, the syntactic, lexical and rhetorical structures of AJE's online news article were examined to determine its local meaning. Within the ideological analysis, the AJE's online news article was analyzed to determine its ideological positive "Self" (in-group) and negative "Other" (out-group) presentations. The study is an attempt to explain how a single reality-Egyptian internal conflict- is viewed and represented by the designated media outlet, AJE. This can be achieved within the framework of critical discourse analysis (CDA). To conduct this qualitative study, the researchers adopted van Dijk's theory of Macrostructures (1980), van Dijk's theory of ideological square (1998) and Wodak's approach of Discourse- historical (2001, 2009). Furthermore, Fairclough's model for media discourse analysis was utilized to organize the analytical process. The study approved that AJE succeeded to reflect its ideological view. It expressed its support to the Muslim Brotherhood (Islamists) presented as the positive "Self" (in-group) and antagonism against the new Egyptian authority presented as the negative "Other" (out-group).
\end{abstract}

Keywords: Critical Discourse Analysis (CDA); Media Discourse; Ideology; Macro and Micro Structures; "Self" and "Other" presentations; AJE

\section{Introduction}

Media news representation cannot be regarded as a direct and easy reproduction of events as it involves a process of selecting, structuring and formulating such events via language (Fairclough, 1995b). Language is, then, the main tool to persuade people to accept certain representations of news events which must be organized logically and naturally for the sake of spreading the views of dominant people and then accepting them as common -sense knowledge providers (Fairclough, 1995b). In this sense, all news representations are reported from a particular angle due to the fact that all media institutions and organizations are politically, socially and financially situated (Fowler, 1991).

The application of critical discourse analysis (henceforth CDA) to analyze online news article helps create and increase awareness and deep understanding of the linguistic strategies used to construct "Self" and "Other" ideological representations. Thus, in this study, it is considered as a viable approach to unearth the implicit ideologies hidden in the AJE's online discourse. As such, the researchers of the present study intend to concentrate on the ideological use of language to build the "Self" and "Other" polarities embedded within the AJE's online news article.

Hence, by using language as a tool of control and conviction, AJE works hard and exert its efforts to persuade people, manipulating their minds and, then, mastering their opinions and tendencies. CDA can be used as an effective method to uncover implicit ideologies and power utilized through language by those in power to control opinion for their advantage (Widdowson, 2007). Up to this point, the researcher concludes that such ideologies can be studied to understand the function of AJE's discourse linguistically and ideologically.

Manipulation of people's minds is the main reason behind certain strategies being followed by news agencies to embed certain ideologies within their coverage of world news. The main assumption is that the AJE's media language is manipulated to serve their powerful elite: Qatari governments (Pintak, 2011). By analyzing its online news article, the 
researchers attempts to explore AJE's hidden ideologies, examining its intended strategies to manipulate people's minds. To achieve this goal, AJE online news text will be analyzed by looking at the micro and macro structures showing how its language is manipulated for the purpose of persuading and controlling people's minds.

\subsection{Objective}

The present study aims to identify the semantic macro and micro structures of AJE's Arab spring online article and its ideological representations of "Self" and "Other" towards the Egyptian internal conflict. As such, it will be an attempt to answer the following question:

1) What are the semantic macro and micro structures of AJE's Arab spring online article and its ideological representations of "Self" and "Other" towards the Egyptian internal conflict

\subsection{Theoretical Framework}

The proposed model of CDA adopted in this study is based on:

1. Van Dijk's Semantic Macrostructures Theory (1980a, 1980b; 1988) which shows the linguistic analysis of the news text on both levels: macro and micro. The current study focuses on the both levels as the macro propositions (themes) and micro structures of AJE's news article will be shown and analyzed.

2. Van Dijk's Ideology Square Theory (1998) which shows the in-group and out-group ideological presentations; and

3. Wodak's Historical Approach (2001, 2009) to connect the linguistic - ideological analysis with Intertextual analysis by background information that facilitates the process of news text understanding.

The first van Dijk's two theories examine the cultural, social, political and ideological factors affecting AJE's news text that concerns with the Egyptian internal conflict after the Arab spring whereas Wodak's approach is utilized to show the historical and political information that may help clarify the reason behind AJE's ideological view. The two theories and approach will be discussed below.

\subsubsection{Van Dijk's Theory of Semantic Macrostructures}

Van Dijk (1980a, 1980b; 1988) provided a method to analyze the structural organization of news text. According to him, news reports have a hierarchal schema named a superstructure that has certain categories, with the most important details come before the less important ones. The global superstructure represents the overall structural organization of a news text which covers the main event, commentary, background and evaluation categories. Each category is associated with a topic or a macroproposition. The news text covers many macropropositions which can be reduced to the main one that summarizes the news text as a whole. The textual-structural categories can be exploited to steer the reader's comprehension and interpretation.

Van Dijk (2009, p.68) believed that semantic macrostructures should be the first step in analyzing the text to be studied: "I often advocate beginning Critical Analysis [...] with an analysis of semantic macrostructures, that is, with a study of global meanings, topics or themes". Thematic structures or topics are derived from the text itself. Sentences formulate topics covered within the text, representing macro-propositions. These macro-propositions, in turn, can be reduced to more general ones. These general ones should be cut down to one main macro proposition that represents the whole item of the news story (van Dijk, 2009). The analyst and reader's prior-knowledge about the topic in question helps infer many macro-propositions (van Dijk, 1988b). This theory will be utilized to analyze the headlines and the body of AJE's news report, under study.

\subsubsection{Van Dijk's Theory of Ideological Square}

Defining ideology as a basic shared, socio-cognitive system of a group, culture or society, van Dijk (1998a) suggested the ideological square to be applied to analyze any type of a news text, showing our positive Self-presentation and their negative Other-presentation. Words may be exploited to refer to ideological conventions, creating a suitable model in the readers' minds (Ali, 2011). This notion facilitates the comprehension of these news texts, influencing the reader's interpretation of them. The present paper utilizes the ideological square to interpret AJE's positive "Self" (in-group) and negative "Other" (out-group) as far as the Egyptian event is concerned.

\subsubsection{Wodak's Historical-Discoursal Approach}

Wodak's approach $(2001,2009)$ provides background information with which the discursive event is embedded. Hence, it is useful to expose the implicit meaning of a news text to be explicit by relating it to the relevant historical -sociopolitical situations in which it happened. Such information will be of a great help to guide the reader to comprehend the news text. This method can be used with the analysis of semantic macrostructures or with the ideological analysis. To comprehend the Egyptian communicative event, it is useful to apply this approach to achieve an objective analysis. AJE's ideological view can be understood by integrating the historical, socio and political context with the whole process of analysis.

The two theories and approach support each other, working together to create and clarify the overall meaning of the news text, in question.

\subsubsection{Fairclough's Three-Dimensional Approach (1995a)}

Fairclough's Three-dimension approach of CDA (1995a) will be utilized in the present study. It consists of three dimensions or steps (description, interpretation and explanation) which will be followed by the researcher throughout the process of analysis of the AJE's selected news article to manifest its positive "Self" (in-group) and negative "Other" (out-group). 'Description' is connected with the linguistic part of analysis while 'interpretation' and 'explanation' are connected with the ideological part of the analysis. In fact, this approach connects the two levels of analysis, micro and 
macro together. Thus, the linguistic structures are described linguistically and, then, interpreted and explained, ideologically. In other words, the first step is concerned with the linguistic analysis while the other two steps are concerned with the ideological one. That is to say, the linguistic analysis serves to achieve the ideological analysis which concerns with overall theme or topic of the news story. As such, the linguistic analysis and ideological analysis will be linked together, achieving the main target of the current study.

The study's theoretical framework will be illustrated in the following figure (1):

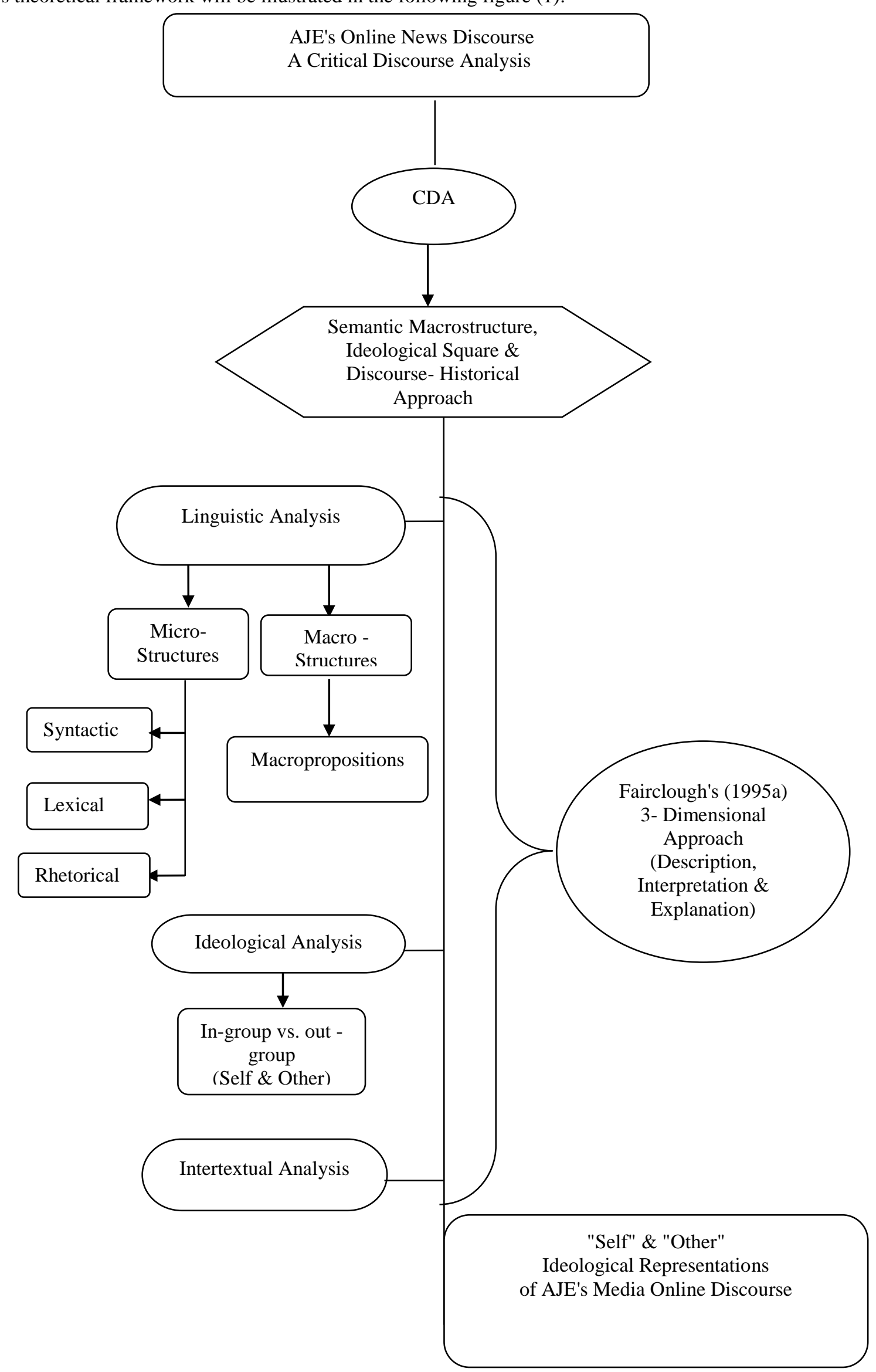

Figure 1. Theoretical Framework 


\section{CDA Analysis of AJE's Article}

AJE's news story is titled:" Egypt widens crackdown on Muslim Brotherhood". It is released on its website on 27 December 2013. It deals with the Egyptian coup authority' crackdown campaign launched against Muslim Brothers and their supporters after the Islamist President Mohammad Morsi has been toppled out of power in Egypt. It provides a full account of the new Egyptian rulers' severe policies and actions aiming to eliminate Muslim Brothers' role in Egyptian society after one year being in power. Massive protests have been spread in many cities; Cairo, the capital, is the first. AJE's news report reflects the Egyptian political scene after the Arab spring started in February 2011 with President Mohammad Hosini Mubarak's step down from power. AJE documented the event aiming to present the positive "Self" and negative "Other" reflecting its ideological attitude towards the Egyptian political conflict. To facilitate the process of overall analysis, sentences in the text are numbered.

\subsection{Semantic Macro Structure Analysis}

The following section will deal the with semantic micro structures of AJE's news story article showing how its ideological view of positive "Self" and negative "Other" is reflected towards the Egyptian internal conflict.

\subsubsection{Thematic structures}

AJE's news story consists of 18 sentences, covering two parts; 12 sentences in the first part and 6 sentences in the second part. Starting with the title "Egypt widens crackdown on Muslim Brotherhood", it may have the following possible macro-propositions:

1) Egypt expands its campaign against Muslim Brotherhood.

2) Muslim Brotherhood is regarded, now, an illegal organization in Egypt.

3) Egyptian seculars, who are the powerful force, now, fight the Islamic-oriented people controlling the whole country.

The above-mentioned macro-propositions can be summarized to the main one. It is "The Egyptian powerful secular's authority expands its crackdown campaign to terminate Muslim Brotherhood organization". The suggested semantic macrostructure will be echoed within the readers' minds when they have some historical information facilitating their understanding.

The suggested semantic macrostructure for the headline reflects the secular interim authority's power supported by General Abdul- Fatah el-Sisi. It raises numerous questions the readers try to find answers for as why did the Egyptian new interim authorities launch its crackdown against the Islamists and what did the Islamists commit during that year of their ruling ended with a coup toppling them successfully. AJE directs the readers' attention to the military campaign launched by the Egyptian new interim authority against Muslim Brotherhood's members and supporters. This is the main goal of AJE aiming to shed light on, heavily. It aims, by such goal, to focus on the oppression and injustice the Islamists surrounded by after the military Coup. This will be clarified throughout the AJE's whole text so as the AJE's ideology concerning the Egyptian event.

Within AJE's news story, topics are built in a hierarchical way with which the important main event, crackdown on Muslim Brotherhood members and supporters, comes first. Other topics are mentioned and included (S.1-S.18), later consequently. As such, many topics are included within AJE's article; which are related to the main one. Thus, AJE's text yields the following macro-propositions:

M1: Muslim Brotherhood is regarded as a terrorist organization included within the ban-black list according to the interim government's decision (S. 4 and S.7).

M2: Calls to provoke violence against police and security forces are opposed severely (S.4).

M3: Clashes erupt between Muslim Brotherhood's supporters and security forces leading to the killing of a police man (S.5).

M4: General Abdul-Fattah, the minister of defense and head of the coup threatened that Egypt will fight Islamic terrorism (S.6).

M5: Through a telephone call with his Egyptian counterpart, Nabeel Fahmi, American secretary of state, John Kerry, condemns the crackdown campaign against the Muslim Brotherhood's members and supporters, expressing USA's worries about human rights in Egypt (S.9 and S.11).

M6: American condemnation of the suicide bombings in Mansoura and Cairo is declared (S.10).

M7: Daily protests and demonstrations calling for the toppled President Morsi's return back to power six months after ousting him in a military coup are continued (S. 12).

M8: Life-imprisonment punishment against any person convicted legally of Muslim Brotherhood membership and support financially and in terms of information is announced (S.13).

M9: Many charities that work hard to help the needed people and families in the poor areas shut downed out of their fear of any responsibility charges of terrorism against them (S. 16).

M10: Egypt witnessed many suicidal bombings in el-Mansoura, leading to the killing of 14 innocent victims, and Cairo, wounding five policemen (S.10, S.17 and S.18).

The above-listed macropropositions can be, in turn, outlined in the following ones below.

M11: Muslim Brotherhood is blacklisted as a terrorist organization, leading to provocative calls to escalate violence against security forces amid continuation of public protests and demonstrations six months after President Morsi's oust out of power in a military coup that led to severe clashes between his supporters and interim government-new rulers ' 
ones amid General Abdul-Fattah el-Sisi's threat of terminating Islamic terrorism represented by Muslim Brotherhood (S.1, S.2, S.3 and S.6).

M12: By the words of its secretary of state, John Kerry, USA condemned and criticized crackdown on Muslim Brotherhood and spread of violence and suicidal blasts in al- Mansoura and Cairo resulted in the killing of innocent 14 in the first and wounding 5 policemen in the second amid continuous clashes between supporters of both, Muslim Brotherhood and the new secular rulers-interim government (S. 9, S.10, S.11, S.12, S.17 and S.18).

\subsubsection{Derivation of Semantic Macrostructure}

The above two macro propositions can be finally reduced into in a general macro-proposition (M13) formulating the main semantic macroproposition of AJE's news article that concerns with the Egyptian political landscape post the Arab spring 2011. However, the macro-proposition suggested for AJE's news story titled 'Egypt widens crackdown on Muslim Brotherhood' can be suggested below.

Amid escalation of public protests and confrontational demonstrations continued for six months after the Muslim Brotherhood President Morsi's oust out of power in a military coup headed by General AbdulFattah el-Sisi who threatened to fight what he called Islamic terrorism, the interim government supported by the army, expands its crackdown on Muslim Brotherhood which led to retaliated suicide bloody bombings in el-Mansoura killing 14 innocent people; and Cairo wounding 5 policemen and this promoted the USA 's government, in the words of secretary of state, John Kerry, to express worries condemning both.

To sum up, the researchers' suggested semantic macrostructure outlines AJE's news, reflecting its "Self" and "Other" ideological view as far as the Egyptian internal conflict is concerned. In other words, AJE's ideological attitude can be outlined as follows:

1) AJE supports the Muslim Brotherhood which came to power after free legal elections presenting it as the positive "Self"

2) AJE antagonizes the military-secular authority which has revolted against the legal government of the Islamists presenting it as the negative "Other"

Thus, AJE's ideological representation of "Self" and "Other" is vivid reflecting the positive self-presentation for the first (in-group) and negative other presentation for the second (out-group). This matches van Dijk's Ideological Square (1998).

\subsubsection{AJE's Semantic Macrostructure and van Dijk's Ideological Square}

A close reading of the suggested semantic macrostructure shows that AJE's news text reflects the following two groups:

1) AJE's positive "Self"; which is represented by:

a) The Muslim Brotherhood organization

b) Its affiliates and supporters.

This group stands for the Egyptian Islamists reflecting the oppressed community in Egypt. It is represented by the Muslim brothers who came to power after free elections winning the majority vote. They ruled Egypt for one year but they were overthrown out of power in a military coup. Furthermore, they faced detention and illegal judgments; their elect-president was the first.

By such indication, AJE asserts two facts about this group:

i) It is the oppressed group which is deprived of its legal right to rule Egypt after winning the election.

ii) It is the strong group as it declares its campaign to revolt against the suppressive illegal authority.

Thus, AJE expresses positive reaction for the Muslim Brotherhood's affiliates and their supporters regarding them the legal and legitimate rulers of Egypt and their president Morsi is the legal and legitimate president of Egypt. Thus, it adopts their position backing their rights to regain power, sympathizing with their demands and throwing all its weight behind them.

To sum up, AJE draws this group positively as a positive power that resists the new authority. As such, it presents it as the positive "Self" (in-group) that should be glorified, endorsed and supported in its struggle to regain its right.

2) AJE's negative "Other"; which is represented by:

a) The Egyptian coup authority

b) Its government, supporters and followers.

This group stands for the Egyptian new authority that came to power in an illegal coup toppling the free elected President Mohammad Morsi and jailing him and his followers of Muslim Brotherhood. Furthermore, this group rejects the Islamic rule in Egypt due to its secular-free orientations. By such indications, AJE asserts the following two facts about this group:

i) It is the oppressing group that took power from its legitimate winners of election.

ii) It is the weak group as it failed to stand in front of the Muslim brothers who launched a wide campaign to regain their rights. 
Thus, AJE expresses a negative reaction against the new authority which came to power illegally in a military coup headed by General el-Sisi, the Muslim Brothers' minister of defense, and his supporters. Throughout its article, AJE shows antagonism against this group, regarding it as the illegal authority of Egypt. Thus, AJE opposes its position rejecting its ill-legal rule. To sum up, AJE draws this group negatively as a negative power that revolted against legitimacy in Egypt. As such, it presents it as the negative "Other" (in-group) that should be criticized, rejected and antagonized.

Finally, the researcher summarizes AJE's ideological view of "Self" and "Other" as the Egyptian internal conflict is concerned as follows:

a) AJE supports Muslim Brotherhood organization defending its struggle against the coup authority. Thus, it endorses it as the legitimate ruling authority drawing it positively. Hence, it legitimizes its right to regain power in Egypt.

b) AJE antagonizes the coup authority standing against its action to take power illegally. Thus, it antagonizes it drawing it negatively. Hence, it delegitimizes its policies and actions against Muslim Brothers.

In a nutshell, the suggested semantic macrostructure reflects the AJE's ideological view of "Self" and "Other" vividly. It adopts the Muslim Brothers ' position and opinion presented as the positive "Self" and regarded as the legitimate rulers of Egypt. At the same time, it rejects the secular authority' position and opinion presented as the negative "Other" and regarded as the illegitimate rulers of Egypt. It supports the first and antagonizes the second. As such, the suggested semantic macrostructure is connected with van Dijk' ideological square of positive "Self" (in-group) and negative "Other" (out-group) presentation.

\subsubsection{AJE's Semantic Macrostructure and Wodak's Discourse-Historical Approach}

Background information help understand AJE ideological view towards the Egyptian internal crisis. Van Dijk and Kintsch (1983) stated that an event can be easily understood by means of background information. It is worthy to mention that AJE is the mouth of the Qatari Government. Thus, its stance towards Egypt is not contrary to that one of Qatari government which swore hostility against President Mohammad Hosni Mubarak's authority aiming to play the main political role in the international and Arab forums instead of Egypt.

To go deep further, Qatar is a small state in its size but so rich in wealth and financial resources. Furthermore, it has good relations and ties with the USA, the biggest state in the world. To eliminate the Egyptian role and influence, the Qatari government worked hard to bring down President Mubarak's regime throughout its support for the public uprising against him. This is well reflected by AJE within its media coverage and live transmission supporting the uprising that ended with Mubarak's decision to step down in February 2011.

Due to its religious orientation, Qatari government endorses the Muslim Brotherhood's first government in Egypt supporting it with all its financial and media capabilities. As it is the Qatari government's main news outlet, AJE throws its weight behind the Muslim Brothers supporting them by being their media mouth they need to express their position to the Arabs and the whole world especially after the military coup headed by General el-Sisi. This can be noticed within its 24-hour media coverage. The under-study article is a good evidence of AJE's supportive policy for the Muslim Brotherhood as the bulk of its coverage was devoted to attack the coup authorities exposing their policies and plans in Egypt.

\subsection{Semantic Micro Structures Analysis}

Within the following section, the semantic syntactic, lexical and rhetorical structures within AJE's news article will be described, interpreted and explained, focusing to show their role in framing AJE's ideological view of positive "Self" and negative "Other" concerning the Egyptian internal conflict.

\subsubsection{Syntactic Structures Analysis}

Within AJE 's news story, various syntactic structures have been utilized to achieve its main aim of showing support for Muslim Brotherhood and full antagonism for the Egyptian new authority. Two categories will be investigated, below.

\subsubsection{Actor Role}

The AJE's whole article covers many different actors. It is easy for the readers to notice that the actors in the news text are divided into three groups. AJE concentrates on them to serve its main goal to endorse the positive "Self" (Muslim Brotherhood) in its position against the negative "Other" (Egyptian authority). The first two actor groups are the main ones as they represent the two main conflicting powers in Egypt. The first group is the oppressing power which denotes the Egyptian new authority. It embodies the negative role of the Egyptian authorities played against Muslim Brotherhood, the organization and affiliates. This power is represented by 'Egypt' (S.1 and S.6), 'the interim authorities' (S.2 and S.3), 'security forces' (S.5) and 'governmental actions' (S.16). Here, AJE draws a negative picture for the Egyptian authority which is described as 'Egypt' in two places and 'interim authorities' in a third place whereas in the fourth one, it is connected with cruel actions against Muslim Brotherhood's affiliates.

The second group is the oppressed power which denotes Muslim Brotherhood organization. It embodies the positive role of the organization and its members and supporters who suffer under the oppression of the Egyptian new authority. This group is represented by, 'the detained people' (S.4) and 'Muslim Brotherhood' (S.12), directly, to shed the light on its activities intensely in Egypt referring to its affiliates' daily protests and demonstrations to demand the return back of legitimacy. It can be fulfilled by the toppled President Morsi's return back to power. This is what AJE, itself, insists on showing, first, support for him, in particular, and, second, for Muslim Brotherhood, in general. For AJE, Muslim 
Brotherhood's members are the owners of a legitimate right giving them the right to continue daily demonstrations in the past six months.

In fact, this group is connected with the first one completing each other as the actors of the first group (the Egyptian authority and its supporters) launched a campaign to fight the actors of the second group (Muslim Brotherhood and its affiliates). The detained people (S.4) were arrested due to their role in provoking violence which the Egyptian authority (first-group actor) intended to accuse its opponents (second-group actor) of. As a result of the standoff between the two actors, 'clashes' (S.5) and 'blasts' (S.18) became the fact that the Egyptian society cannot deny. In other words, AJE intends to indicate that the clear result of confrontations between the actors of group (1) and group (2) would be clashes and blasts. First, 'clashes' (S.5) between the supporters of the two sides became a daily habit in the Egyptian street. Then 'blasts' (S.18) became a loud voice in the Egyptian arena, claiming the lives of innocent people.

The third group of actors, the American power, is represented by the American secretary of state, John Kerry, who tried to be fair between the two parties of the Egyptian conflict to satisfy both of them. First, he criticized the interim government for its actions against the Muslim Brotherhood and its supporters. Then, he condemned the blasts which led to the death of innocent victims (S.9). In both roles, Kerry serves the AJE's aim, indirectly, in criticizing the new authority in Egypt as it is the reason behind what the Muslim Brotherhood's members and supporters suffer from. Then, it is the reason behind the safety vacuum resulted in the last blasts in al-Mansoura and Cairo. Thus, the third group's actor endorses AJE's main aim.

To sum up, the AJE's "Self" and "Other" line separating between the two sides of the conflict in Egyptian political scene is clearly drawn. It supports the Muslim Brotherhood representing the positive "Self" and antagonizes, the Egyptian authority, the negative "Other".

2.2.1.2 Reporting past event

In its news story, AJE depends mainly on past tense structures. The grammatical categories are classified into three groups. They will be analyzed and discussed below.

First Category: Passive Voice

'(were) arrested' (S.2) is an agentless passive. While the preceded patient is 23 supporters of the Muslim Brotherhood, the agent can be easily known, the Egyptian authority which launched a severe crackdown against them. The patient is preceded for the sake of emphasis. Verb (be) is omitted for the sake of brevity. 'Were accused' (S.4) is used to refer to the fact that many people were arrested for two things: 1) passing leaflets to promote Muslim Brotherhood's ideology, and 2) causing violence in Egypt. It is an agentless passive. But the agent is known for all.

Second Category: Simple Past

'Blacklisted' (S.3) is the main event that Muslim Brotherhood faced after the interim government 'declared' (S.7) its decision regarding the organization as a terrorist group. This allows the arrest of tens of members and supporters of the organization. Thus, the Egyptian interim authority should carry the responsibility of the blasts that 'rocked' (S.17) different parts in Egypt and 'killed' (s.18) many innocent people. This forces the greatest state in the world, USA, to criticize the whole situation as John Kerry, the secretary of state, 'expressed' (S.9 and 11) worries and 'condemned' (S.10) what happened in Egypt.

Third Category: Past Continuous

'Were protesting' (S.5) reflects what the Muslim Brotherhood used to do on a daily base since Islamist President Morsi's toppling. The past continuous structure is used to describe the continuous protests in the past six months to regain the legitimacy of power. The continuous protests assert the Islamists' steadfastness, strength and firm belief in their cause. AJE aims to end with this for the sake of supporting the positive "Self" in the latter's conflict with the negative "Other" reflecting its policy and strategy concerning Egypt after the Arab spring.

Conducting the syntactic structure analysis, it is clear that AJE succeeds in utilizing all the available syntactic structures to show its ideological view towards Egyptian internal crisis reflecting the positive "Self" (Muslim Brotherhood) in its struggle against the negative "Other" (Egyptian new authority).

\subsubsection{Lexical structures Analysis}

AJE's lexical words and expressions will be analyzed to reveal how they are exploited to serve its "Self" and "Other" ideological view concerning the Egyptian internal conflict.

\subsubsection{AJE's Register of War against Muslim Brotherhood}

This register is reflected by various lexical words and expressions covering the whole AJE's news article. 'Crackdown' (S.1) is the first term used by AJE to show the oppression and injustice the Islamists surrounded by in Egypt. They face a severe campaign under the umbrella of law to terminate their influential political role. It is referred to them directly by their organization's name 'Muslim Brotherhood' (S.1). It is a war against them launched by the new authority' affiliates aiming to eliminate their power. This meaning is embedded within certain lexical terms and words throughout the news article. The lead sentence asserts this meaning with more direct details. 23 citizens are detained (S.2) on suspicion of belonging to Muslim Brotherhood only. This organization is accused of terrorism as it is denoted as a 'terrorist group' (S.2) after one day of being included in 'the blacklist' (S.2). Here, AJE criticizes the unfair operations taken against the Islamists in Egypt. Hence, it selects its words, accurately, to express oppression and injustice the Islamists surrounded by. 
c) A terrorist organization (S.2)

d) The group was blacklisted (S.2).

It is unjust arrests of 23, at least, for only suspecting to belong to Muslim Brotherhood denoting it as a terrorist organization being included in the blacklist released by the new authority. In fact, the headline (S.1) and lead (S.2) of the news article embody the main message of AJE briefly by asserting that the problem in Egypt is the Islamist face oppression unfairly. Thus, terms like 'crackdown', 'a terrorist organization' and 'blacklisted' are not used but for reflecting what the Muslim Brotherhood suffers from under the rule of the interim government in Egypt. Terms like 'a terrorist organization' and 'blacklisted' are repeated again in S.3 for the sake of emphasizing this meaning directing the readers' attention to the Islamists' suffering.

'Violence' (S.4) is the main accusation the Muslim brothers are convicted of by the Egyptian authority to justify their arrests and crackdown; the interim authority tries to persuade the public inside and outside Egypt. The Islamists are accused, here, with violence, unrest and confusion in the whole country leading to a confrontation with police force (S.4). To deepen the suffering of Islamists, one of their supporters was killed in clashes with citizens of Cairo (S.5).

'Terrorism' (S.6) is repeated as it is used to denote Muslim Brotherhood. Here, Muslim Brotherhood is attributed with terrorism that the Egyptian army will confront strongly. More information are provided about arrests of Muslim Brotherhood's members and supporters, one day after being blacklisted as 'a terrorist group' (S.7). Repetition serves its purpose of deepening the meaning. More details are provided about the interim government's decision threatening of imprisonment for 5 years, at least, for any kind of help and support given by anyone to the Muslim Brotherhood. Moreover, the participation in 'pro-Muslim Brotherhood rallies' or having their literature (S.8) will be punished. Furthermore, AJE's reporter asserts that the punishment will reach life imprisonment (s.13).

'Profound' is an adjective modified by 'really' and 'quite' (S.14) to direct the readers' attention to the fact that the suffering Islamists surrounded by is something big and scary. The three words are used to reflect the hard situation Muslim Brotherhood face in Egypt after the military coup. 'A lot of charities' (S.16), belonged to Muslim Brotherhood, stopped their financial grants for people in the poorest areas of Egypt due to their fears of any punishment they might face according to the government's decision. This means that the poor people will be deprived of any financial help Muslim Brotherhood's charities can provide them with. Here, AJE tries to describe Muslim Brotherhood as a charity organization, not as a terrorist one.

Throughout this register, AJE aims to provide the readers with the interim authority' view about the Muslim Brotherhood, depicting it as a terrorist organization. At the same time, it succeeds to correct such negative view about the Islamists and their organization. Furthermore, it succeeds in exposing the interim authority's evil plan to deform them. Thus, AJE is keen to reflect the Muslim Brotherhood positively whereas the Egyptian interim authority, negatively.

2.2.3 Rhetorical Structures Analysis

Within this part of the study, information sources and numbers will be analyzed, explaining how AJE utilizes them for the sake of reflecting its ideological view concerning "Self" and "Other" as far as the Egyptian communicative event is concerned.

\subsubsection{Information Sources}

AJE depends on many official and media information sources to prove its credibility and objectivity in dealing with the Egyptian conflict.

First information source: General Abdul-Fattah el-Sisi. AJE depends on a direct quotation taken from his speech. "Egypt will stand firmly in confronting terrorism and the people will never be afraid as long as the army is present", said Egyptian chief General Abdel Fattah el-Sisi, during an army graduation ceremony on Thursday in Cairo (S.6).

In his message to Muslim Brotherhood, General el-Sisi, as the army's chief, threatens its members and supporters that Egypt 'will stand' against the terrorism 'firmly' and Egyptian people will be safe 'as long as the army is present' (S.6). Here, el-Sisi threatens with a confident tone that he will put an end to Muslim Brothers, kicking them out of power and the Egyptian political scene as if he wants to prepare them for the worse in the near future.

Within his threat, el-Sisi denotes Muslim Brotherhood as 'terrorism' that cannot be accepted. Thus, it should be fought, firmly. By asserting this point, he tries to justify the next severe crackdown on Muslim Brotherhood, using future tense to warn its affiliates of the miserable end they will face. With this threat, AJE sheds light on the cruelty of the new rulers of Egypt, represented by el-Sisi, in their tendency towards Muslim Brotherhood. It sympathizes with Muslim Brothers that they will face ominous end by Egypt's new rulers. In fact, this can be regarded as a good attempt to redress them in their struggle with their enemies. With this, AJE expresses its supportive strategy towards Muslim Brotherhood in its struggle with the news Egyptian authority.

Second information source: US Secretary of state John Kerry.

'US Secretary of state John Kerry expressed concern on Thursday over Egypt's intensified pursuit on the Muslim Brotherhood in a phone call with his counterpart in Cairo Nabil Fahmy' (S.9).

AJE depends on US Secretary of state John Kerry, as a second information source, to endorse its view supporting the Islamists and antagonizing the Egyptian authority. In his statement, Mr. Kerry reflects the American point of view towards Egypt, in general, and Muslim Brotherhood, in particular. He criticizes the crackdown campaign against Muslim Brotherhood's members and supporters calling to stop human rights violations. This serves AJE's main aim in strengthening the position of Muslim Brotherhood in Egypt. 
Third information source: State Department spokeswoman.

'Kerry condemned a suicide bombing in Mansoura on Tuesday and Thursday's bus bombing in Cairo, State Department spokeswoman Jen Psaki said in a statement (S.10). The Top American diplomat also "expressed concern about the interim Egyptian government's December 25 terrorist designation of the Muslim Brotherhood, and recent detentions and arrests", Psaki said' (S.11).

Jen Psaki, State Department spokeswoman, is the third information source AJE depends on to provide the readers with more information about the American reactions towards Egypt. American spokeswoman reflects the American condemnation of the suicidal blasts quoting the Secretary of State, John Kerry. She criticizes the bombings directly clarifying Kerry's opinion, and then, USA's. This means that the USA rejects that innocent people pay their souls for nothing, but follies of politicians. Interestingly, she does not accuse the Muslim Brothers of the bombings, with no reference to any connection. This, in fact, can be regarded as an indirect support to the Muslim Brothers. The USA, as the biggest state in the world, does not neither accuse them nor agree with Egyptian authority' in its accusation to them. AJE insists on focusing on this point. AJE regards the American spokeswoman's statement as a real support to the Muslim Brothers in their struggle against the Egyptian new authority. In fact, it is not, only, America's view but AJE's, too.

\section{Fourth Information Source: AJE's reporter}

Al-Jazeera's Peter Greste, reporting from Cairo, said that anyone convicted of being a senior Muslim Brotherhood member, or of financing or providing information to the group, could face life imprisonment (S.13).

This is part of AJE correspondent's report informing the readers that life imprisonment will be the punishment for anyone seeks to help Muslim Brotherhood with information or finance. Greste's report serves two purposes:

a) Focusing on Egyptian authority' cruelty and injustice in its decision to punish Islamists in this way.

b) Directing the international public opinion to stand with the Muslim Brothers in their conflict with the Egyptian new authority.

According to Greste, Muslim Brothers face a difficult time. As such, they need support and help inside and outside Egypt. The two functions serve AJE's aim in mobilizing the public opinion everywhere to support Muslim Brotherhood. AJE's reporter, Greste, continues providing information.

"The effect of this is really quite profound. It's not just the people that are actively promoting Brotherhood ideology. There are a lot of charities that the Brotherhood also supports who work works across the poorest areas of Egypt, and those groups already started closing down their operations", Greste said (S.14, S.15 and S.16).

Greste's direct quotation clarifies that the Muslim Brothers are not the only affected ones by the Government's campaign against them. Thousands of poor people will lose the financial help they receive every month as tens of charity groups are forced to stop their operations and charity activities fearing of life imprisonment. With this note, AJE intends to say that Muslim Brothers play a charity role in Egypt paying thousands of poor people financial grants monthly. Furthermore, the new Egyptian authorities do not pay Egyptian poor people any attention putting their suffering aside. Taken the poor's financial problem as a pretext, AJE intensifies its indirect calls for the international community to take any action to support the Muslim Brothers. Otherwise, they will be terminated.

Throughout the four information sources, AJE's ideological view concerning the two conflicted parties in Egypt becomes clear. It supports the Muslim Brothers and antagonizes the Egyptian new authority, military and civil.

\subsubsection{Numbers}

The number is the rhetorical device used to achieve credibility and trust. Any news story agency depends on numbers to establish both goals. Van Dijk (1988a and b) asserted that numerical information can be regarded as a scale to measure the degree of both credibility and truth of information within news report. AJE seeks to assert its credibility by utilizing numerical information aiming to achieve persuasion. Throughout the text, many references to numbers can be noticed and will be discussed, below.

At least '23' supporters of Muslim Brotherhood were arrested a day after it was blacklisted (S.2). The same information is repeated for the sake of emphasis (S.2 and S.3). 'One person' (S.5) was killed in clashes between Muslim Brothers and their opponents in Cairo. 'Five years' (S.8) is the punishment for anyone who helps the Muslim Brothers. '25 December' (S.11) is an important date for both the government and Muslim Brotherhood as the first issued its decision to prohibit the second that revolts against it, strongly. Thus, this date cannot be forgotten or ignored by both of them. But for AJE, it is the date of infantilizing democracy in Egypt not just as a judicial political decision. As such, it should be emphasized.

'Six months' (S.12) after President Morsi's fall down, the demonstrations continued to protest the military coup against him. Here, AJE asserts that the public opinion rejecting Morsi's fall is still influential in the Egyptian political scene having a great public support. The adverb 'nearly' means that the specified time is more or less than six months. In both cases, it is an enough time to the Muslim Brother's affiliates and supporters to show their stance endorsing their organization. This indicates that the whole issue is still an issue of public opinion in Egypt reflecting the organization's hardness, steadfastness and its ability to deliver its message. It is what AJE intends to direct its readers to believe in. 'A lot of' (S.16) is an adjective used to refer to the charities that started to close its doors in compliance with the interim government's decision. In fact, 'a lot of' means that the number of closed charities is big but it has not been defined. 
AJE ends its news story with reference to the numbers of suicidal blasts' victims. In the first blast, '14' innocent people were killed and '1' person (woman) was injured whereas in the second, '5' policemen were wounded (S.18). By such reference, AJE aims to assert a fact that the deterioration in the political situation leads to a real security disorder. Innocent people pay their lives as a result. Interestingly, AJE does not refer to any accusation directed against Muslim Brothers.

To sum up, AJE utilizes its micro structures to assert its ideological attitude towards the Egyptian internal conflict. It supports Muslin Brotherhood representing the positive "Self" and antagonizes the Egyptian new authority representing the negative "Other

\section{Conclusion}

Throughout its news article, AJE deals with the Egyptian internal conflict erupted between Muslim Brothers and the new Egyptian authority. With noticeable determination, AJE concentrates on Muslim Brotherhood's struggle to regain its legitimate right of power after its elected President Mohammad Morsi's toppling by the new coup authority. AJE is keen to provide the readers with a full account of the internal crisis between the two powers of the Egyptian conflict; the oppressing Egyptian coup authority and the oppressed Muslim Brotherhood. Furthermore, AJE succeeds to clarify its ideological view of "Self" and "Other" towards these to powers.

To sum up, AJE expresses:

1) Full support for the Muslim Brothers presenting them as the positive "Self" and reflecting their cause, positively.

2) Full antagonism for the Egyptian coup authority presenting them as the negative "Other" and reflecting their cause, negatively.

This representation is vivid and well-established in the whole news text analyzed. As such, AJE's news article is connected with van Dijk's Ideological Square of positive "Self" (in-group) and negative "Other" (out-group) presentation. The CDA study of AJE's news story titled 'Egypt widens crackdown on Muslim Brotherhood' will be summarized in the table 1 below.

Table 1. Summary of AJE's Case Study

\begin{tabular}{|c|c|c|}
\hline Category & Theme & Ideological Representation \\
\hline $\begin{array}{l}\text { 1)Semantic } \\
\text { Macrostructure }\end{array}$ & $\begin{array}{l}\text { - Crackdown on Muslim } \\
\text { Brotherhood } \\
\text { - violence and blasts } \\
\text {-American condemnation of both }\end{array}$ & $\begin{array}{l}\text { Positive for Muslim Brotherhood } \\
\text { Negative for Egyptian authority }\end{array}$ \\
\hline $\begin{array}{l}\text { 2)Syntactic } \\
\text { structures }\end{array}$ & & \\
\hline Actor role & $\begin{array}{l}\text { To establish three groups of } \\
\text { explicit actors: Muslim Brothers, } \\
\text { Egyptian coup authority, and the } \\
\text { USA. }\end{array}$ & $\begin{array}{l}\text { Positive for Muslim Brotherhood } \\
\text { Negative for Egyptian authority }\end{array}$ \\
\hline $\begin{array}{l}\text { Reporting past } \\
\text { event }\end{array}$ & $\begin{array}{l}\text { To inform about past event } \\
\text { To provide background } \\
\text { Information and historical facts }\end{array}$ & $\begin{array}{l}\text { Positive for Muslim Brotherhood } \\
\text { Negative for Egyptian authority }\end{array}$ \\
\hline 3)Lexical structures & & \\
\hline $\begin{array}{l}\text { War against } \\
\text { Muslim } \\
\text { Brotherhood } \\
\text { register }\end{array}$ & $\begin{array}{l}\text { To show the severe crackdown on } \\
\text { Muslim Brotherhood }\end{array}$ & Negative for Egyptian authority \\
\hline $\begin{array}{l}\text { 4)Rhetorical } \\
\text { structures }\end{array}$ & & \\
\hline Information sources & $\begin{array}{l}\text { To assert credibility, truth \& } \\
\text { objectivity }\end{array}$ & $\begin{array}{l}\text { Positive for Muslim Brotherhood } \\
\text { Negative for Egyptian authority }\end{array}$ \\
\hline Numbers & $\begin{array}{l}\text { To endorse credibility, trust \& } \\
\text { Objectivity } \\
\text { To assert facts, evidence \& truth }\end{array}$ & $\begin{array}{l}\text { Positive for Muslim Brotherhood } \\
\text { Negative for Egyptian authority }\end{array}$ \\
\hline
\end{tabular}

The following figure 2 outlines AJE's ideological representation of positive "Self" and negative "Other" for its case study that concerns with the article titled 'Egypt widens crackdown on Muslim Brotherhood'. 


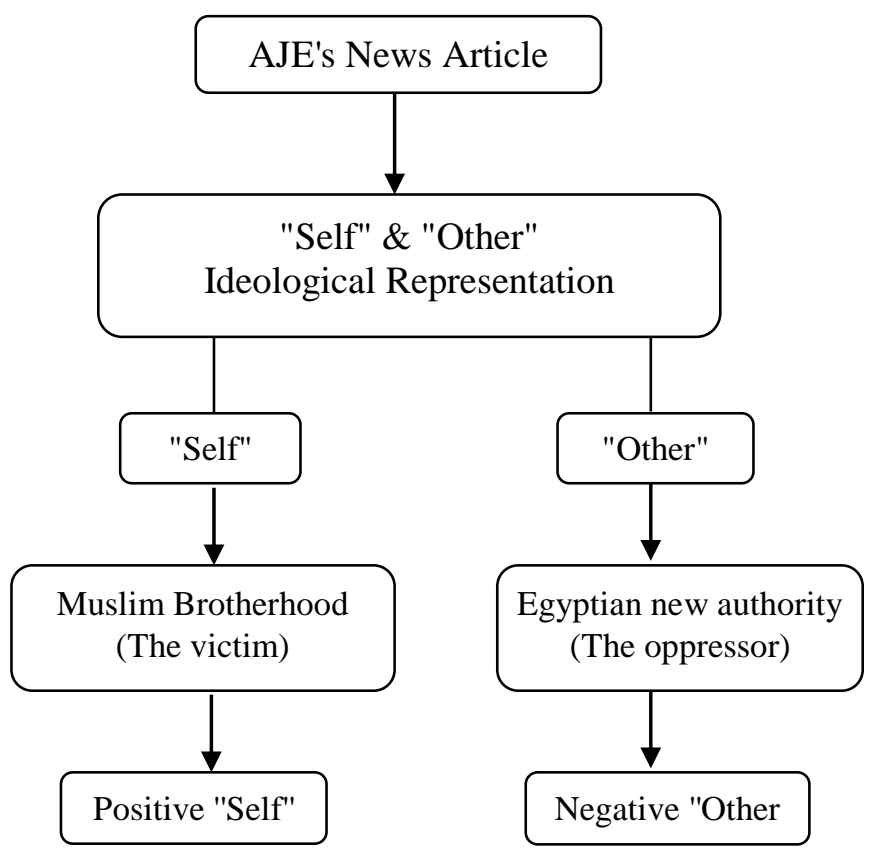

Figure 2. AJE 's Ideological Representation

\section{References}

Ali, G. (2011). Hero or terrorist? A comparative analysis of Arabic and Western media depictions of the execution of Saddam. In Discourse \& Communication. London: Sage, 5(4) 301-335.

Ali, G.A.(2004). English headlines in the Arabic press: a comparative study from an ideological perspective. Unpublished doctoral dissertation, Universiti Sains Malaysia. Malaysia

Bell, A. (1991). The Language of news media. Oxford: Basil Blackwell, Inc.

Bell, A. and Garret P. (1998). Approaches to media discourse. Oxford: Blackwell Publisher

Ben Ammar, T. (2009). The language of terrorism / Al-Jazeera and the framing of terrorism discourse. Retrieved July 282012 from ProQuest Dissertations and Theses Abstract.

el-Nawawy, M. and Powers, S. (2010). Al- Jazeera English: A conciliatory medium in a conflict -driven environment? Global Media and Communication, 6:61. London: Sage

Fairclough, N. (1995a). Critical discourse analysis: the critical study of language. London \& New York: Longman Fairclough, N. (1995b). Media discourse. New York: Arnold.

Firdous, T. 2009. Al Jazeera English, Presenting a non-Western viewpoint and contesting Western media dominance during the Gaza crisis. Retrieved November 32012 from ProQuest Dissertations and Theses Abstract.

Fowler, R. (1991; 2013). Language in the news: Discourse and ideology in the press. New York and London: Routledge

Pintak, L. 2011, "English Lesson": The moment has arrived for Al-Jazeera English ,except in the US. Columbia Journalism Review, 2011

Ross, G. (2008). Introducing War: Visual Analysis of Online Media Discourse on Forces and Weapons of the Iraq Conflict. Carleton University

van Dijk, T.A. (1980). Macrostructures: An interdisciplinary study of global structures in discourse, interaction, and cognition. New Jersey, U.S.: LEA

van Dijk, T.A. (1988). News as discourse. Hillside, NJ: Erlbaum

van Dijk, T.A. (1998). Ideology: a multidisciplinary approach. London: sage.

van Dijk, T.A. and Kintsch, W. (1983). Strategies of discourse comprehension. New York: Academic Press.

Widdowson, H.G. (2007). Discursive analysis. Oxford: Oxford University Press

Wodak, R. (2001).The discourse -historical approach. In: R. Wodak \& M. Mayer (Eds.), Methods of critical discourse analysis (pp.63-94). London: Sage

Wodak, R. and Meyer, M. (2009). Methods of critical discourse analysis. London: Sage. 


\section{Appendix: AJE's News Story}

1) AJE: Egypt widens crackdown on Muslim Brotherhood

2) At least 23 supporters arrested on suspicion of belonging to a terrorist organisation, day after group was blacklisted.

3) Egyptian authorities have arrested 23 Muslim Brotherhood supporters on accusations of belonging to a terrorist organisation, a day after the country's interim government blacklisted the group.

4) The people arrested on Thursday were accused of passing out leaflets in support of the Brotherhood, promoting the group's ideology, and inciting violence against the Egyptian security services, according to Egypt's state media agency, MENA.

5) Later on Thursday, one person was killed as student supporters of the Brotherhood clashed with residents of a Cairo district where they were protesting.

6) "Egypt will stand firmly in confronting terrorism and the people will never be afraid as long as the army is present," said Egyptian army chief General Abdel Fattah el-Sisi, during an army graduation ceremony on Thursday in Cairo.

7) The arrests come only a day after Egypt's interim government declared the Muslim Brotherhood, to which deposed former President Mohamed Morsi belongs, a terrorist group.

8) The designation means anyone accused of taking part in pro-Muslim Brotherhood rallies, possession of the group's literature, or supporting the group "verbally or in writing" could be sentenced to five years in prison, the Interior Ministry said.

9) US Secretary of State John Kerry expressed concern on Thursday over Egypt's intensified pursuit of the Muslim Brotherhood in a phone call with his counterpart in Cairo Nabil Fahmy.

10) Kerry condemned a suicide bombing in Mansoura on Tuesday and Thursday's bus bombing in Cairo, State Department spokeswoman Jen Psaki said in a statement.

11) The top American diplomat also "expressed concern about the interim Egyptian government's December 25 terrorist designation of the Muslim Brotherhood, and recent detentions and arrests," Psaki said.

12) The Brotherhood still organises almost daily protests demanding Morsi's return, nearly six months after he was overthrown following widespread popular protests.

Life imprisonment

13) Al Jazeera's Peter Greste, reporting from Cairo, said that anyone convicted of being a senior Muslim Brotherhood member, or of financing or providing information to the group, could face life imprisonment.

14)"The effect of this is really quite profound. It's not just the people that are actively promoting Brotherhood ideology.

15) There are a lot of charities that the Brotherhood also supports who work right across the poorest areas of Egypt, and those groups have already started closing down their operations," Greste said.

16) The arrests on Thursday also come after two bombings rocked Egypt earlier in the week.

17) On Tuesday, a blast at a police station in the Nile Delta city of Mansoura killed 14 people and wounded many others, while another bomb exploded near a bus in Cairo on Thursday, wounding five. 